\title{
Integrating Multicultural Education in School Curriculum
}

\author{
Supsiloani ${ }^{1}$ Badaruddin ${ }^{1, *}$ Rizabuana Ismail ${ }^{1}$ Dara Aisyah $^{1}$
}

\author{
${ }^{1}$ Anthropology Study Program, Universitas Sumatera Utara, Medan, Indonesia \\ *Corresponding author. Email: badaruddin@usu.ac.id
}

\begin{abstract}
Education in the era of science, technology, and information is a topic that always attracts attention for all people, especially education stakeholders and education practitioners. The discourse of multicultural education is aimed at responding to the phenomenon of social, cultural and ethnic conflicts that often occur in society with a multicultural face. Collecting data in this study using qualitative methods related to issues of multicultural education in schools. The research informants consisted of the Medan City Education Office, Principals, Teachers, and Curriculum experts. This study concludes the importance of multicultural education as a learning process providing equal opportunities to the whole community without differentiating treatment. Because differences in ethnicity, culture, and religion are unique pieces of evidence that must be kept intact strengthen the unity and integrity, the image of the nation, the identity of the nation in the eyes of the world.
\end{abstract}

\section{Keywords: Integration of Multicultural Education, Multicultural Education, School Curriculum}

\section{INTRODUCTION}

Multicultural education positions schools in an important and strategic place. Schools are considered capable of functioning as a basic institution or vehicle for the transformation of society and eliminating the pressures and injustices that often arise. Therefore, multicultural education strongly opposes discrimination and various forms of racism in schools and society, and accepts and understands the reality called pluralism (race, ethnic, language, religion, economy, and gender) that exists in the lives of students, teachers, and society. . The implementation of education plays an important role in realizing a multicultural-based unity forum, given that differences should not be a differentiator or obstacle, but can also be used as a foundation for mutual understanding's existence. It is clear that Indonesia in this profile needs an educational model that can accommodate cultural diversity. The current Indonesian context, according to Saliman \& Complete (2013), starting from the facts of national history, political policies, and facts of globalization, requires that the younger generation (especially students in schools) need to be equipped with multicultural education.

The concept of multicultural education rolls over as the main discourse and becomes the consumption of reason for practitioners and the people of several countries that have implemented educational models in multicultural education on a concrete basis. This is done as an effort to educate the nation and to summarize diversity on a national scale, including countries that have previously implemented this model, namely the UK, Australia, and Canada. The main motive is none other than the awareness of the importance of multicultural education for a pluralistic society. Formally, the Indonesian people recognize the existence of diversity, but in reality, it is hard to impose the desired ideals.

Along with the times that are influenced by globalization, there are many socio-cultural crises in society. For examples such as declining respect for and compliance with the law, ethics, morals, social decency, and other social ills. According to Palipung (2016), one of the strategic efforts that can be done to build such a 
culture-aware future generation is through giving the value of diversity, namely multicultural education.

\section{LITERATURE REVIEW}

\section{Multicultural Education}

The strategy of multicultural education according to Yaqin (2005:23) has long been developed in Europe, the United States, and other developed countries. This strategy is the development of intercultural studies and multiculturalism. In its development, this study became a special study on multicultural education which was initially aimed at making the majority population able to be tolerant of new immigrants. This study also has a political goal as a means of social control of the rulers over their citizens, so that the condition of the country is safe and stable.

Multicultural education is defined as education about cultural diversity in response to cultural and demographic changes in each environment and society. This is in line with the opinion of Paulo Freire in Arifudin (2007) states that education is not something that tries to move away from cultural and social realities, but education must be able to create a social order that only glorifies social prestige due to the prosperity and wealth it experiences.

The term multicultural education can be used at both a normative and descriptive level to describe educational issues or relating to a multicultural society. In addition, it also includes an understanding of the considerations of educational strategies and policies in society. In a descriptive context, multicultural education must include themes of tolerance, human rights, ethnic and religious differences, the dangers of discrimination, democratization, plurality, universal humanity, and others.

According to Rosyada (2014) multicultural education is still interpreted as very diverse, and there is no agreement as to whether Multicultural education connotes education about cultural diversity, or education to form an attitude of respect for cultural diversity. Kamanto Sunarto in Rosyada (2014) explains that multicultural education is education for cultural diversity in society and sometimes it is also interpreted as education to foster an attitude of respect for cultural diversity.

Therefore, it is very clear that this multicultural education aims to provide an understanding of diversity and the benefits of differences to foster high tolerance for students (Purba, 2019). according to the understanding of multicultural education, the author's view, whatever the definition given by education experts is the fact that the Indonesian nation consists of many ethnicities, with cultural, religious, racial, and linguistic diversity. Indonesia has a philosophy of different tribes, ethnicities, languages, religions, and cultures, but has one goal, namely the realization of a strong, sturdy Indonesian nation, has a strong identity, is respected by other nations so that the ideals of the founding fathers of the nation are achieved. Advanced, just, prosperous, and prosperous. For this reason, according to Rosyada (2014) all components of the nation must be able to without distinction of race, ethnicity, culture, religion, and build strength in all fields, so as to achieve mutual prosperity.

Therefore, they must respect each other, remove religious and cultural barriers. All of that, as stated by Azra (2003) who states that it is not something that is taken for granted but must be pursued through a multicultural education process, namely education for all, and education that pays serious attention to the development of tolerant attitudes, respect for ethnic differences, culture, and religion, and provide civil rights including to minority groups. Thus, multicultural education in this context is defined as a process that provides equal opportunities to all children of the nation without discriminating against ethnicity, religion and culture as well as providing equal rights for ethnic minorities and strengthening unity and integrity.

This is in line with what was expressed by Badrudin (2015) that the purpose of multicultural education is to help all citizens acquire the knowledge, attitudes, and skills needed to carry out their role as effectively as possible in democracy. always communicate with citizens from various groups to create a moral society.

\section{RESEARCH METHOD}

Collecting data use qualitative methods. As qualitative research is one type of research that understands and explores meaning in a number of groups or individuals originating from social problems (Creswell, 2014). The function of theory later in this research is as a guide, reference, guide, or guide so that the focus of research is in accordance with the facts in the field. The location taken in this study was determined purposively, namely Medan City. The collection technique was done through observation, 
interviews, documentation, and FGD. Researchers have determined several relevant informants in answering the problems they want to collect. The research informants consisted of the Medan City Education Office, Principals, Teachers, and Curriculum experts.

\section{RESULT AND DISCUSSION}

\section{Integrating Multicultural Education in School Curriculum}

According to Law Number 20 of 2003 concerning the National Education System, education functions to "develop capabilities and shape the character and civilization of a dignified nation in the context of educating the nation's life, aiming to develop the potential of students so that they can become human beings with noble character, faith, and health. , capable, knowledgeable, creative, independent, and become a democratic citizen. The demands of the education function require citizens who have character and have a noble character, who is democratic and responsible, therefore, Multicultural learning is a demand for national education, because multicultural education is in accordance with its function as the formation of the character of citizens directed at intercultural harmony (UNESCO).

Multicultural education according to Palipung (2016) provide educational concepts and strategies based on the use of pluralism for the community, especially students of different status, culture, ethnicity, religion, language and others. The most important approach is through multicultural education, the educational strategy is not only aimed at making students it is not difficult to understand the lessons learned, but also to raise their awareness to behave humanist, democratic and pluralist.

Multicultural education according to Palipung (2016) offers an alternative through the application of educational strategies and concepts based on the utilization of the diversity that exists in society, especially that of students such as ethnic diversity, culture, language, religion, social status, gender, ability, age, and race. The most important approach is through multicultural education, the educational strategy is not only aimed at making students easy to understand the lessons they are learning, but also to increase their awareness to always behave in a humanist, pluralist, and democratic manner.
Schools play a role in instilling multicultural values in students. If from the beginning they already have the values of tolerance, togetherness and respect for differences, then these values will be reflected in their behavior. If this is successfully possessed by the younger generation, then the future life can be predicted to be relatively peaceful and full of respect for each other can be realized.

The implementation of multicultural education with the curriculum, according to Arifudin (2007) should not change the curriculum. Multicultural lessons can be integrated into other lessons. However, guidance is needed for teachers in implementing it. The most important thing is that students need to be taught about tolerance, togetherness, human rights, democratization, and mutual respect. This is very valuable for their provision of life in the future and very important for upholding human values.

The implementation of multicultural education with the curriculum in different countries is different. When looking at one example of multicultural education in America, as quoted by Tilaar from the results of Banks' research in Semiawan (2004) that the implementation of multicultural education in America includes various dimensions, namely:

1. Dimensions of the curriculum, namely that the cultural norms that will be conveyed to students are integrated with a subject, with a clear formulation of competencies.

2. The scientific dimension, namely that the scientific formulation of the cultural norms and rules that will be conveyed is formulated through a historical research process by looking at the historical experiences of figures who are very consistent in fighting for multiculturalism.

3. Fair learning treatment, namely that the treatment in learning must be delivered fairly and fairly, without differentiating the treatment of those who come from certain ethnicities, or certain economic strata.

4. Empowerment of school culture, namely that the school environment as a hidden curriculum must provide support for the development and fostering of multiculturalism, both in the provision of learning facilities, worship facilities, administrative services, and various other services. Empowerment is important in various aspects, including in terms of school curriculum with local content. The importance of empowerment in various aspects was stated by Badaruddin, et.al. (2020) that 
empowerment has several aspects, namely economic, social, and institutional aspects.

By citing the American experience, the procedure that must be taken in implementing multicultural learning in Indonesia, it is by compiling a curriculum that contains various competencies in relevant subjects, because multiculturalism is just a movement. Then, followed by the formulation of various materials in accordance with the competencies to be achieved and continued with the formulation of the learning process that provides more opportunities for students to foster and develop attitudes.

\section{CONCLUSION}

According to the analysis above, it is concluded that multicultural learning is based on the concept of difference which is unique to each society. The concept of multiculturalism is closely related to the formation of a society based on Bhinneka Tunggal Ika and to create a national culture that is unifying for the Indonesian nation. However, in its implementation, there are still various obstacles that prevent the formation of multiculturalism in society. So it's important to integrate multicultural education in the curriculum in schools because schools are places to socialize learning.

\section{REFERENCES}

1. Arifudin, Iis, 2007. The Urgency of Implementation of Multicultural Education in Schools. Jurnal Insania, Vol.12. No. 2.

2. Azra, Azyumardi, 2003. Multicultural Education; Rebuilding Indonesia Bhineka Tunggal Ika. Jurnal Tsaqafah, Vol. I, No. 2.

3. Badaruddin Badaruddin, Kariono Kariono, Ermansyah Ermansyah \& Lina Sudarwati (2020) Village community empowerment through village owned enterprise based on social capital in North Sumatera, Asia Pacific Journal of Social Work and Development, DOI: 10.1080/02185385.2020.1 $\underline{765855}$

4. Badrudin, 2015. The Concept of Multicultural Education, Its Existence and Urgency Values in Indonesia. Jurnal Tazkiyah, Vol. 16 No. 2.

5. Creswell W. J, 2014. Qualitative Inquiry \& Reserch Design, Choosing Among Five Appoaches, Third Edition, Sage ISBN,978-14129-9530-6

6. Depdiknas.(2003). RI Law No. 20 of 2003, concerning the National Education System. Jakarta: Depdiknas.

7. Lengkap, N., \& Saliman, M. P. (2013). College Excellence Research Endorsement Page.

8. Palipung, Nuhraini, 2016. Implementation of Multicultural Education at Taman Muda Elementary School Inclusive Mother Pawiyatan Taman Siswa Yogyakarta. Jurnal Kebijakan Pendidikan Edisi 5 Vol. V.

9. Rosyada, Dede, 2014. Multicultural Education in Indonesia A Conceptual View. Jurnal Sosio Didaktika, Vol. 1 No. 1.

10. Semiawan, Conny, 2004. The Challenge of a Multicultural Education in a Pluralistic Society; the Indonesian Case. Jurnal Multicultural Education in Indonesia and South East Asia, Edisi I.

11. Purba, A. S., Malihah, E., \& Hufad, A. (2019). The implementation of multicultural education in senior high schools in Medan. Budapest International Research and Critics Institute (BIRCI-Journal): Humanities and Social Sciences, 2(3), 226-233.

12. Yaqin, Ainul M. (2005). Multicultural Education Cross - Cultural Understanding for Democracy and Justice. Yogyakarta: Pilar Media 